TECHNICAL TRANSACTIONS 10/2017

CZASOPISMO TECHNICZNE 10/2017

MECHANICS

DOI: $10.4467 / 2353737$ XCT.17.178.7286

\author{
Zbigniew Dziopa (zdziopa@tu.kielce.pl) \\ Department of Computer Technologies and Armaments, Faculty of Mechatronics \\ and Machine Design, Kielce University of Technology
}

\title{
Krzysztof Zdeb
}

Forensic Laboratory, Police Headquarters in Krakow

\author{
EMPIRICAL RESEARCH OF HUMAN-WEAPON SYSTEM
}

BADANIA EMPIRYCZNE UKŁADU CZŁOWIEK-BROŃ

\begin{abstract}
Rapid firing of the Skorpion vz.61 machine gun was registered at a police shooting range. The shooting was executed by a policeman from the secret service. The registration was done with the use of a fast digital camera Phantom v9.1 together with the necessary equipment. With the use of the specialised TEMA software, which serves to analyse the recorded image, the courses of the variation of kinematic quantities characterizing the weapon movement were obtained. On the basis of the courses of the variation of the displacement, velocity and acceleration over time, the behaviour of the machine gun in thirteen characteristic points of its operation was specified.
\end{abstract}

Keywords: weapon, human, registration of firing, kinematics of movement

\section{Streszczenie}

Na strzelnicy policyjnej została przeprowadzona rejestracja strzelania ogniem seryjnym z pistoletu maszynowego Skorpion wz.61. Strzaly oddane zostaly przez policjanta ze służb specjalnych. Rejestrację przeprowadzono przy wykorzystaniu szybkiej kamery cyfrowej wraz z niezbędnym oprzyrządowaniem. Przy wykorzystaniu specjalistycznego programu TEMA, stużącego do przeprowadzania analizy zarejestrowanego obrazu, uzyskano przebiegi zmienności wielkości kinematycznych charakteryzujących ruch broni. Na podstawie otrzymanych przebiegów zmienności przemieszczenia, prędkości i przyspieszenia w funkcji czasu określono zachowanie się pistoletu maszynowego w trzynastu charakterystycznych punktach jego działania.

Słowa kluczowe: broń, człowiek, rejestracja procesu strzelania, kinematyka ruchu 


\section{Introduction}

The subject of the research is the Skorpion submachine gun, vz.61, cal. $7.65 \mathrm{~mm}$, as shown in Figure 1. An engineer - Miroslav Rybar from Zbrojovka Brno - started constructing it in 1958. The gun is therefore not the latest design. Its use presented a fairly large dispersion of the bullets fired, especially when shooting from a distance exceeding $25 \mathrm{~m}$. Special units of the army and police are equipped with this type of weapon. The Skorpion submachine gun constitutes only an example of automatic weapons on the basis of which a comprehensive analysis intended to improve its effectiveness will be conducted. Ultimately, the task of the considerations undertaken is to develop guidelines with the aim to shape the dynamic properties of automatic weapons, in order to reduce the dispersion of rapidly fired bullets.

In this paper, the preliminary elements of experimental research are presented, which aim to define the kinematics of the movement of the human-weapon system. With the use of the specialised TEMA software, which serves to analyse the recorded image, the courses of the variation of kinematic quantities characterizing the movement of two weapon points were obtained. On the basis of the courses of the variation of the displacement, velocity and acceleration over time, the behaviour of the machine gun in thirteen characteristic points of its operation was specified.

\section{Operation of the Skorpion submachine gun}

Operation of the Skorpion submachine gun is based on the principle of blowback recoil [1]. The lock is supported by two resistance-return springs. A single or rapid firing is performed with the lock closed. The lock moves in the receiver of a rectangular cross-section that was extruded from a steel plate. The so-called "clips", which serve to tension the lock, move in the extrusions along its both sides. The extractor slot is located at the top of the receiver. Through the slot, the used shells are discharged vertically upwards.

Before loading the cartridge, the lock is located in the front extreme position. Due to the force generated by the resistance-return springs, the lock is pressed against the rear end of the barrel and thus, it locks the barrel with the receiver. The hammer is released and its working surface leans against the rear end of the firing pin.

In order to prepare the machine gun for fire, a loaded magazine needs to be strapped. Then, we release the weapon and vigorously move the lock to the rear most position. The retreating lock turns the hammer, which meshes with the catch. After releasing the lock, the compressed springs of the return device move it forward.

The returning lock hits the cartridge that partially protrudes from the magazine and redirects it to the receiver. At that time, the extractor claw that is supported with the spring moves behind the orifice in the shell. The lock, which is pressed with the springs of the return device against the rear end of the barrel, locks the receiver. After pressing the trigger, the hammer that is released from the catch with the use of the power generated by his spring, 
turns around and hits the end of the firing pin that protrudes from the lock. The firing pin hits the shell with its stricker and a shot is fired.

The pressure of the burnt gases pushes the bullet from the barrel and operates with the same force on the bottom of the shell. By operating on the bottom of the shell, the energy of expanded gases unlocks the receiver and reverses the lock. The shell that moves together with the lock goes to the extractor and is ejected through the extractor slot. The lock turns the hammer again, which compresses his spring. With the setting on continuous fire, the hammer meshes with the catch of the automatic trigger and the hammer catch.

When the retreating lock passes the magazine, the magazine follower using the spring located in the magazine raises another cartridge until it leans against the magazine jaws. The compressed springs of the return device move the lock forward. Then, the lock selects the next cartridge from the magazine and directs it into the receiver. In the final phase, the returning lock, which impacts the lever of the automatic trigger, releases the lock from the automatic catch and after locking the receiver, another shot is fired. The procedure is repeated until the last shot has been fired or the pressure on the trigger has been released. In both cases, the hammer meshes with the hammer catch and firing of subsequent bullets is interrupted.

When the fire selector switch is set to single fire, the lock operates similarly as previously, except that this time, the hammer meshes immediately with the hammer catch and firing of subsequent bullets is interrupted.

\section{Experimental research}

\subsection{Characteristic phases of weapon operation}

Firing the Skorpion vz.61 machine gun equipped with a silencer was registered at the police shooting range. The shots were fired by a policeman from the secret service. The registration was executed with the use of a fast digital camera Phantom v9.1 together with the necessary equipment. A sample picture presenting the shooter holding the weapon while firing two shots - the so-called rapid fire, i.e. consecutive shots at regular intervals specified by the operation of mechanisms of the machine gun, is shown in Fig. 2. When the second bullet leaves the barrel, the shell that was thrown out by the first cartridge is found at the height of the policeman's helmet, making a spherical movement along a curved trajectory.

Two tags - respectively point 1 and point 2, as in Figure 1 - were placed on the silencer and the receiver. With the use of the specialised TEMA software, which serves to analyse the recorded image, the courses of the variation of kinematic quantities characterizing the movement of two chosen points were obtained. In order to perform unambiguous considerations, a coordinate system connected to the Earth was introduced. In the case of the object in question, it might be assumed that this is the topocentric system of Galileo. The beginning of this coordinate system at the start of registration coincides with point 2 , the axis $0 \mathrm{x}$ is directed from point 2 to point 1 , the axis $0 y$ is directed vertically upwards and coincides with the direction of operation of the field of gravitational forces and the axis $\mathrm{Oz}$ is an addition to the orthogonal clockwise Cartesian 


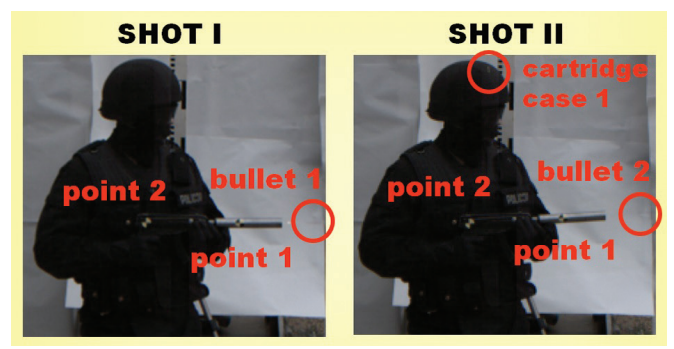

Fig. 1. A police officer while firing two shots from the Skorpion submachine gun

system of reference. Figures from 5 to 19 present the courses of the variation of the coordinates of displacement, velocity and linear acceleration - point 1 and point 2 and angle, angular velocity and angular acceleration in the movement of weapon tilt over time.

The analysis of the graphs was conducted with thirteen characteristic points of operation of the weapon taken into consideration:

a) The first shot $-\mathrm{I}$ (Fig. 2):

1) $t=0.0448[\mathrm{~s}]$ - lock movement to the rear position

2) $t=0.0462[\mathrm{~s}]$ - cartridge bullet 1 leaves the barrel

3) $t=0.0532[\mathrm{~s}]$ - cartridge shell 1 is thrown out of the receiver

4) $t=0.0581[\mathrm{~s}]$ - lock reached the extreme rear position

5) $t=0.0749[\mathrm{~s}]-$ lock movement to the front position

6) $t=0.0973[\mathrm{~s}]$ - lock reached the extreme front position
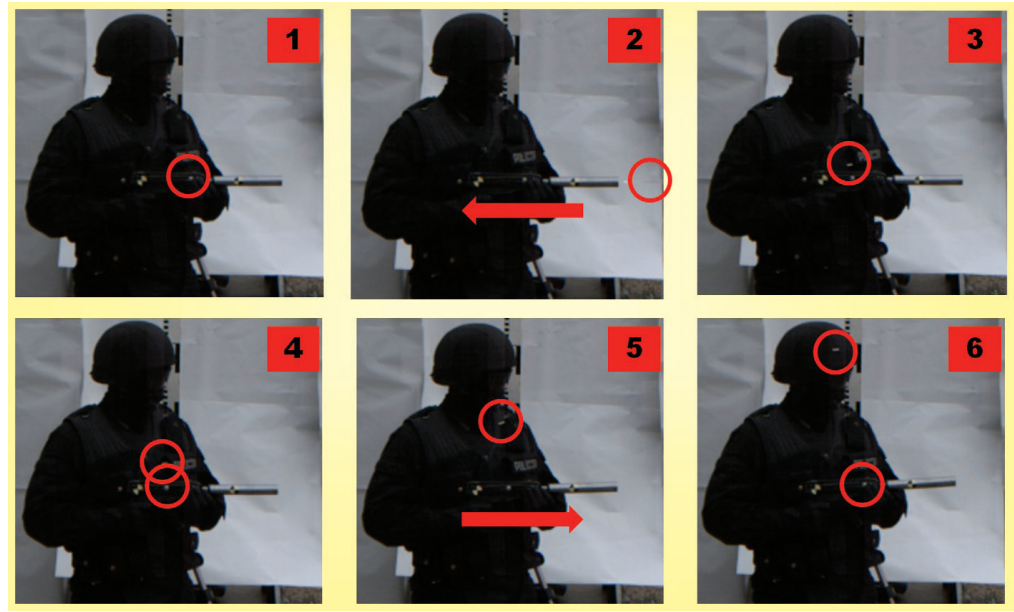

Fig. 2. Characteristic moments of time while firing the first shot

b) The second shot - II (Fig. 3):

7) $t=0.1022[\mathrm{~s}]-$ lock movement to the rear position

8) $t=0.1036[\mathrm{~s}]$ - cartridge bullet 2 leaves the barrel

9) $t=0.1134[\mathrm{~s}]$ - cartridge case 2 is thrown out of the receiver 
10) $t=0.1162[\mathrm{~s}]-$ lock reached the extreme rear position

11) $t=0.1484[\mathrm{~s}]$ - lock movement to the front position

12) $t=0.1743[\mathrm{~s}]$ - lock reached the extreme front position
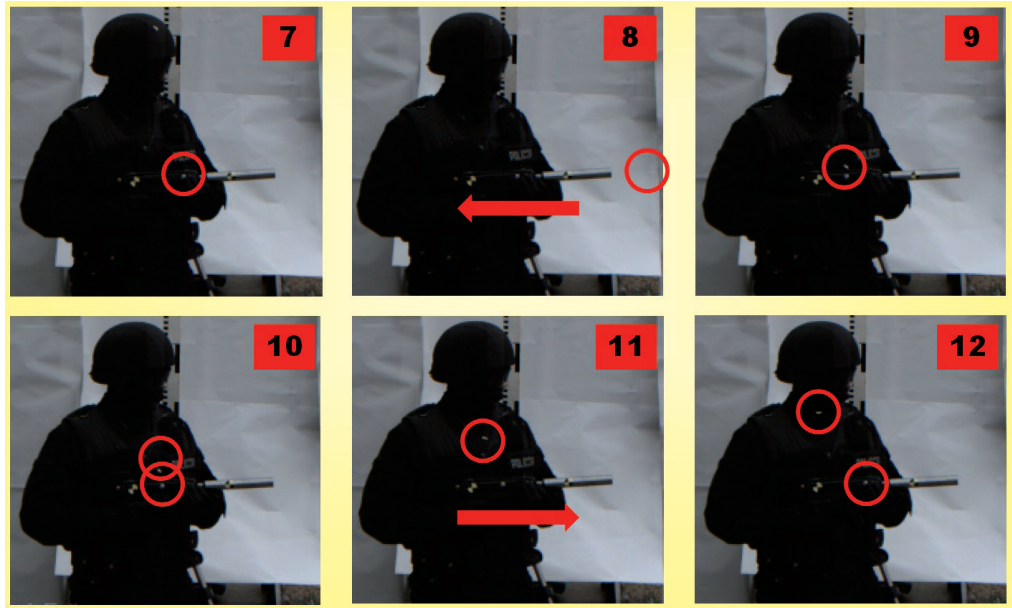

Fig. 3. Characteristic moments of time while firing the second shot

c) The shooter leaves the weapon

13) $t=0.2604[\mathrm{~s}] \quad$ - the end of the observation

\subsection{The course of the variation of kinematic quantities characterising the movement - point 1}

Figures from 4 to 6 show the courses of the variation of kinematic quantities over time characterizing the movement - point 1 in the direction of the axis 0x. Figures from 7 to 9 present the courses of the variation of kinematic quantities over time characterizing the movement - point 1 in the direction of the axis $0 y$. The points indicating specific moments of the time of the weapon operation are plotted onto the graphs.

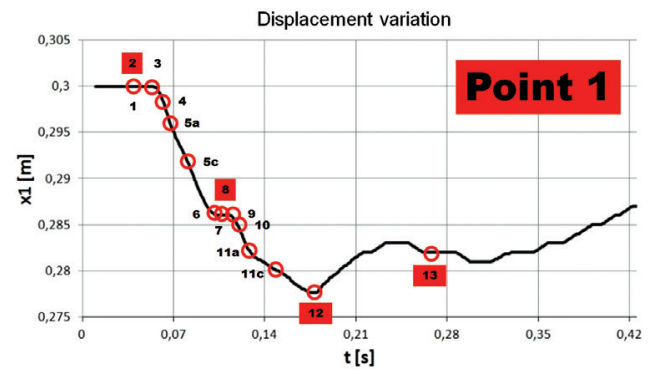

Fig. 4. Displacement of point 1 in the direction of the axis $0 \mathrm{x}$

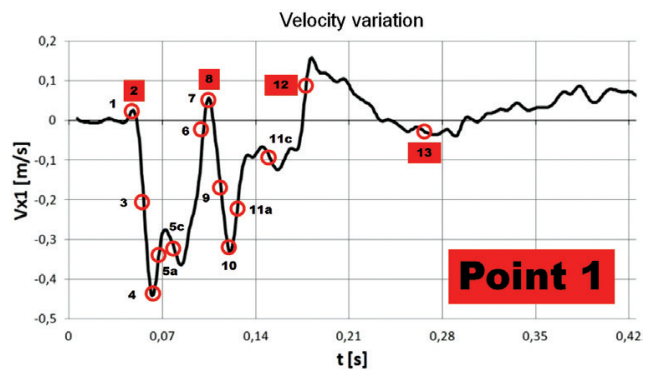

Fig. 5. Velocity of point 1 in the direction of the axis $0 \mathrm{x}$ 


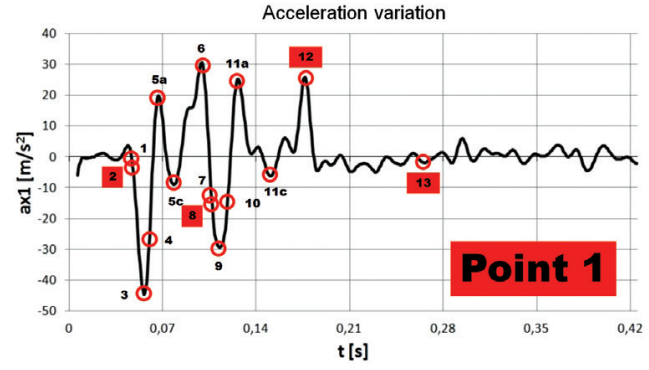

Fig. 6. Acceleration of point 1 in the direction of the axis $0 \mathrm{x}$

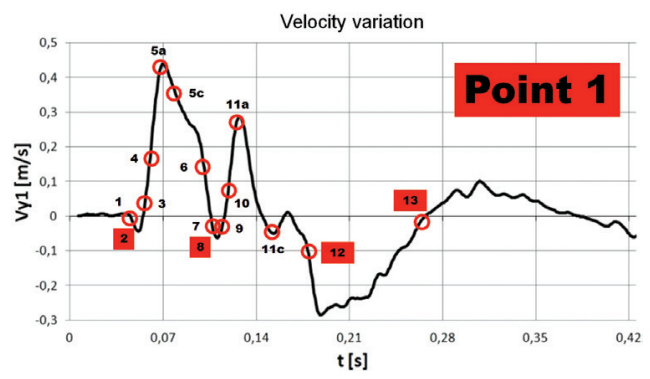

Fig. 8. Velocity of point 1 in the direction of the axis $0 y$

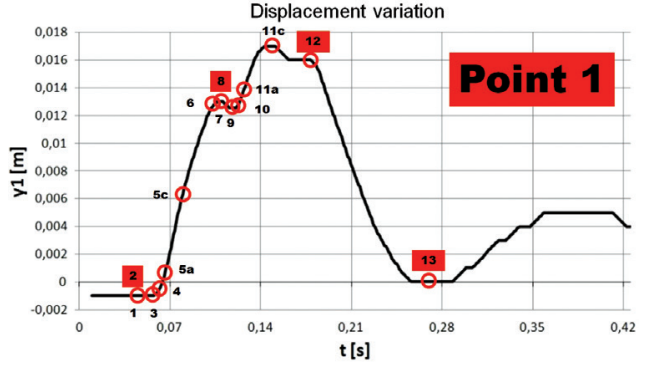

Fig. 7. Displacement of point 1 in the direction of the axis $0 y$

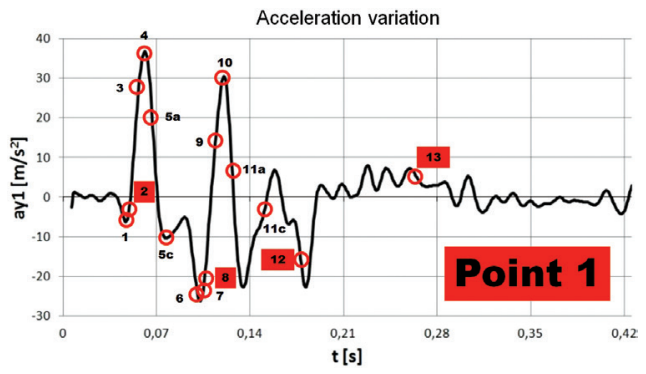

Fig. 9. Acceleration of point 1 in the direction of the axis $0 y$

\subsection{The course of the variation of kinematic quantities characterising the movement - point 2}

As a result of the analysis of the images that were obtained during registration at the shooting range, it might be assumed that all points of the submachine gun move along planes that are parallel to a certain fixed vertical plane. Therefore, the research is limited to the movement of a flat figure. The location of such figure at any point in time is unequivocally defined by the position of the section. For this purpose, it is necessary to determine the position of not only point 1 , but also point 2 .

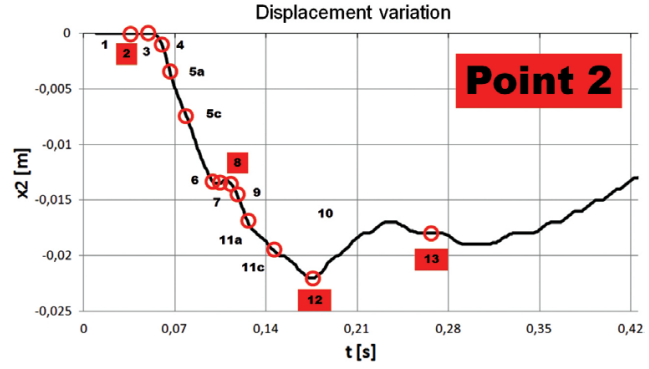

Fig. 10. Displacement of point 2 in the direction of the axis $0 \mathrm{x}$

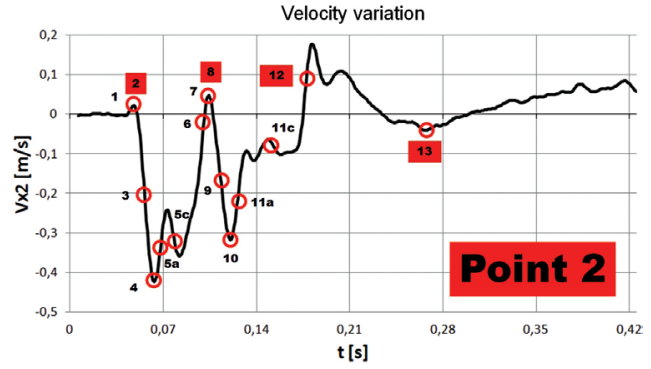

Fig. 11. Velocity of point 2 in the direction of the axis $0 \mathrm{x}$ 
Figures from 10 to 12 present the courses of the variation of kinematic quantities over time characterizing the movement of point 2 in the direction of the axis 0x. Figures from 13 to 15 show the course of the variation of kinematic quantities over time characterizing the movement of point 2 in the direction of the axis $0 y$. The points indicating specific moments of the time of the weapon operation are plotted onto the graphs.

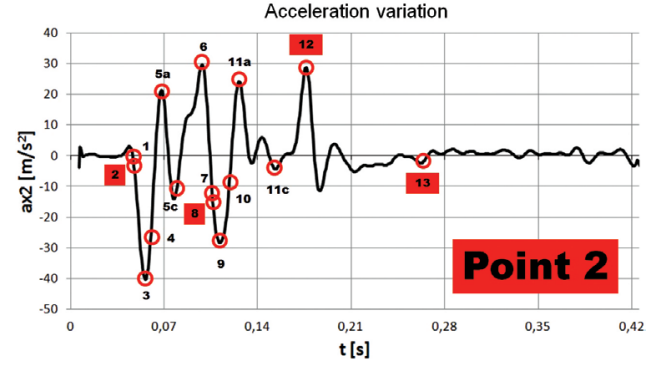

Fig. 12. Acceleration of point 2 in the direction of the axis $0 \mathrm{x}$

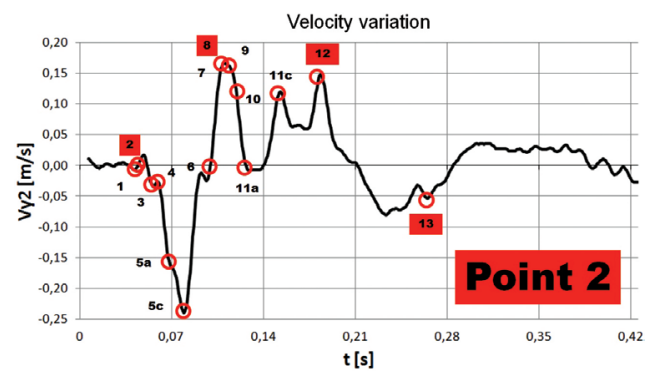

Fig. 14. Velocity of point 2 in the direction of the axis $0 y$

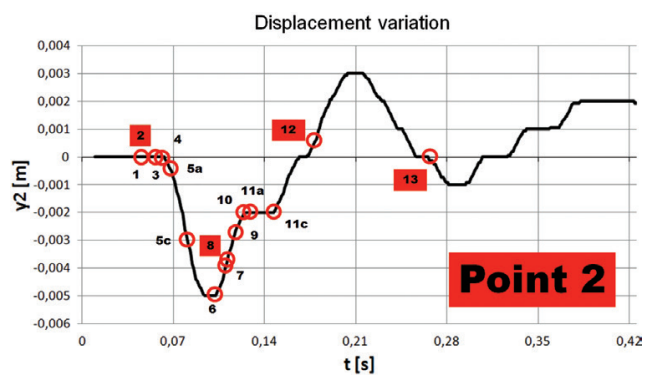

Fig. 13. Displacement of point 2 in the direction of the axis $0 y$

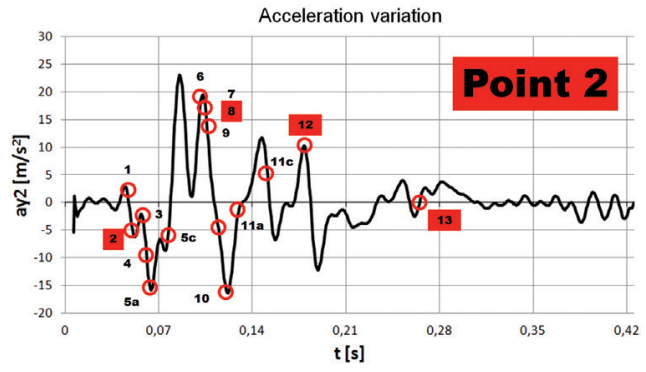

Fig. 15. Acceleration of point 2 in the direction of the axis $0 y$

\section{Elements of biomechanics of the shooter}

A human being is a complex biological system. Its functioning is determined by the current psychophysical state. The fluctuation of the behaviour and the biological features of an individual as well as the wide range of potential people that could use a weapon does not facilitate the research. A unification of the human body is impossible. As far as the biomechanical issue related to a human being is concerned, the spine plays a very important role $[2,3,7]$. It constitutes the central axis of the human body. The main function thereof i.a. is to support and carry the upper body part. It is also the place where bones and muscles related to proper functioning of limbs are attached. Due to its construction, the spine is both strong and very flexible. Its strength depends on the time of load. A too short time of increasing the load does not allow all damping mechanisms to start operating. Such a phenomenon occurs when firing a machine gun. Through the system of shoulder girdle, the spinal load is transmitted to the upper extremities, causing a disorder of precise movements [9]. Through 
the vertebrobasilar connector, vibrations are also transmitted to the head. This can cause significant disturbances of sight fixation and an impairment of visual acuity. In the case of large and sudden loads, displacements of brain structures in a rigid bone box, i.e. the skull, might occur. In such conditions, blood flow through the brain and retina may also be prone to some disturbances. All these phenomena may negatively affect the behaviour of the shooter when shooting personal guns.

\section{Summary}

Rapid firing of two bullets from the Skorpion vz.61 machine gun was registered at the police shooting range with the use of a fast digital camera Phantom v9.1. The tests confirmed the opinion of the users regarding the presence of large dispersion. An acceptable dispersion between two bullet holes should not exceed $0.5[\mathrm{~m}]$ when shooting at the target located at a distance of 25 $[\mathrm{m}]$. Such an assumption stems from the needs of using the weapons, among others, by antiterrorists who must render the enemy powerless without causing casualties among outsiders. Currently, the dispersion of the gun fluctuates within $1.3[\mathrm{~m}]$. Due to the popularity of weapons, the results obtained encouraged the authors to strive to improve its accuracy [4].

This paper presents the elements of experimental studies based on the analysis of the recorded images. The application of standard software as well as the specialized TEMA software allowed to carry out the qualitative and quantitative considerations. During firing, many physical phenomena determine the final effect in the form of weapon accuracy. In this study, the authors focused on research that aimed at defining the kinematics of the movement of the human-weapon system. For this purpose, the courses of the variation of kinematic quantities characterizing the movement of the machine gun were specified. The courses of the variation of displacement, velocity and acceleration over time were obtained, which allowed to determine the behaviour of the machine gun in thirteen characteristic points of its operation [11].

A human being is a complex biological system. In particular, the osteo-muscular system and the nervous system have an impact on human motor activities [8]. Human reaction to the phenomenon of recoil when firing depends on many factors [5]. One of them is the experience of the shooter. In this case, the shooter is a very well-trained policeman from the secret service. The results of experimental studies prove a clear movement of the gun both in the linear and the angular direction. Each of the bullets fired after leaving the barrel performs a different trajectory [6.12]. This is a result of different initial conditions, which are formed while leaving the barrel by the bullet. This leads to unsatisfactory accuracy [4].

Further discussion will aim to use the empirical results to develop a theoretical model taking the relevant physical phenomena and processes into account. Theoretical analysis and motion simulation in virtual space will enable to conduct a thorough study of the dynamics of human-weapon system [10]. The authors strive in their studies to develop guidelines that allow a correction of the dynamic properties of an automatic weapon, and thus, increase its accuracy. 


\section{References}

[1] Białczak B., Podstawy budowy broni lufowej, Skrypt PŚ nr 155, Kielce 1988, 338.

[2] Dziak A., Bóle krzyża, PZWL, Warszawa 1990, 395.

[3] Dziopa Z., Florin-Dziopa I., Analiza komfortu użytkowania przeciwlotniczego zestawu rakiet umieszczonych na samochodzie z wykorzystaniem antropodynamicznego modelu operatora, Czasopismo Techniczne, z. 5/2004, Wydawnictwo Politechniki Krakowskiej, Kraków 2004, 91-98.

[4] Ejsmont J.A., Celność broni strzeleckiej, Praktyczny poradnik, Wydawnictwa Komunikacji i Łączności, Warszawa 2012, 294.

[5] Ewertowski J., Analiza sity oddziaływania broni ramiennej na strzelca $w$ czasie strzału, Biuletyn WAT, vol. LVI, nr 1, Warszawa 2007, 207-221.

[6] Gacek J., Balistyka zewnętrzna, część I Modelowanie zjawisk balistyki zewnętrznej i dynamiki lotu, część II Analiza dynamicznych właściwości obiektów w locie, WAT, Warszawa 1997 i 1998.

[7] Griffin M.J., Handbook of human vibration, Academic Press, London 1990.

[8] Kozubski W., Liberski P.P., Choroby układu nerwowego, Wydawnictwo Lekarskie PZWL, Warszawa 2004, 667.

[9] Książek M., Analiza istniejących modeli biodynamicznych układu ręka-ramię pod kątem wibroizolacji człowieka-operatora od drgań emitowanych przez narzędzia ręczne, Czasopismo Techniczne 2-M/1996, Wydawnictwo Politechniki Krakowskiej, Kraków 1996, 87-113.

[10] Suchocki C., Ewertowski J., Modeling and numerical simulation of semi-automatic pistol Dynamics, Journal of Theoretical and Applied Mechanics, 53, 1, 81-91, Warsaw 2015.

[11] de Silva C.W., Vibration Fundamentals and Practice, Taylor \& Francis Group, Boca Raton, London, New York 2007.

[12] Szapiro J., Balistyka zewnętrzna, Wydawnictwo MON, Warszawa 1956, 468. 